\title{
Correction to: Re-evaluation of biosafety questions on genetically modified biocontrol bacteria
}

\author{
Debora C. M. Glandorf
}

Published online: 16 November 2018

(C) Koninklijke Nederlandse Planteziektenkundige Vereniging 2018

\section{Correction to: Eur J Plant Pathol}

https://doi.org/10.1007/s10658-018-1598-1

The original article has been corrected, as author wanted to cancel Open Access.

The original article has been corrected.

The original version of this article was revised: https://oi. org/10.1007/s10658-018-1598-1

The online version of the original article can be found at https://doi.org/10.1007/s10658-018-1598-1

D. C. M. Glandorf $(\bowtie)$

Department of Gene Technology and Biological Safety, Centre for Safety of Substances and Products, National Institute of Public

Health and the Environment (RIVM, Antonie van Leeuwenhoeklaan 9, 3721 MA Bilthoven, The Netherlands e-mail: Boet.Glandorf@rivm.nl 